Dokuz Eylül Üniversitesi-Mühendislik Fakültesi

Fen ve Mühendislik Dergisi

Cilt 19, Sayı 56, Mayıs 2017
Dokuz Eylul University-Faculty of Engineering Journal of Science and Engineering Volume 19, Issue 56, May 2017

DOI: $10.21205 /$ deufmd.2017195635

\title{
Hava Kireci Harcı Kullanılarak Üretilen Tarihi Yığma Duvarlarda Bünyesel Modelleme
}

\author{
Bilge DORAN*1, Selen AKTAN ${ }^{2}$

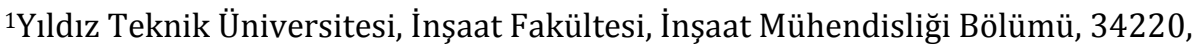 \\ İstanbul \\ ${ }^{2}$ Çanakkale Onsekiz Mart Üniversitesi, Mühendislik Fakültesi, İnşaat Mühendisliği \\ Bölümü, 17100, Çanakkale
}

(Alınış / Received: 26.06.2016, Kabul / Accepted: 06.03.2017, Online Yayınlanma / Published Online: 02.05.2017)

Anahtar Kelimeler Özet: Bu çalışmada, düzlem içi yükler etkisinde kalan tarihi yığma Bünyesel modelleme, Yığma duvar, Sonlu elemanlar yöntemi, Elasto-plastik hasar modeli duvarların üç boyutlu doğrusal olmayan sonlu elemanlar analizi için bir bünyesel modelleme tekniği önerilmiştir. Tarihi yığma yapıların karmaşık mekanik davranışları, büyük ölçüde yapı malzemelerinin kompozit niteliğine bağlıdır. Taş veya tuğla gibi yığma birimlerden ve farklı içeriklerde harç (bağlayıcı) malzemesinden oluşan yığma duvarlarda, zayıf özellikte ve kompozit yapıda olan malzeme harçtır. Tarihi yapılarda kullanılan harcın yı̆̆ma birimlere nazaran mekanik olarak zayıf olması, bu etkiyi sayısal modelleme çalışmalarına yansıtılmasını gerektirmiştir. $\mathrm{Bu}$ kapsamda, modellemede derz bölgelerine yoğunlaşan bir yaklaşım olarak 'sanal birleşim bölgesi malzemesi' tanımlanmıştır. Çalışmada önerilen malzeme modeli, yığmanın gerilme birim şekil değiştirme davranışını ifade etmek üzere, geliştirilmiş von-Mises akma kriteri ile Oliver hasar modeli yaklaşımlarının, ihtiyaç duyduğu malzeme parametreleri dikkate alınarak birleștirildiği elasto-plastik hasar mekaniğinden türetilmiştir. Plastik şekil değiştirme için, kırılma yüzeyindeki çekme ve basınç gerilme değerlerini ayrı ayrı dikkate alan geliștirilmiş von-Mises plastisite modeli ile hasar mekaniğindeki şekil değiştirme artışı Oliver vd. (1990) modeli kullanılarak ifade edilmiştir. Sayısal model sonuçları ve kırılma modları deneysel verilerle karşılaştırılmıştır.

\section{Constitutive modeling of historic masonry walls constructed with non- hydraulic lime mortar}

\begin{tabular}{ll}
\hline Keywords & Abstract: In this study, a constitutive modeling technique for \\
Constitutive & three-dimensional nonlinear finite element analysis of \\
modeling, & unreinforced historic masonry walls under in-plane loading has \\
Masonry wall, & been proposed. The complex mechanical behavior of the \\
Finite element & historical masonry buildings is subjected to the composite \\
method, & characteristics of the materials. Mortar is the vulnerable part of \\
Elasto-plastic & the masonry walls composed with masonry constituents like \\
damage model & stone or bricks and mortars with different contents. It is
\end{tabular}


supposed to reflect the vulnerable behavior of the mortar to the modeling study. In this context, a 'fictitious joint material' approach has been defined. The proposed model was derived from an elasto-plastic damage approach that adapted calibrating the parameters of Oliver's damage model together with the modified von-Mises yield criterion for the masonry constituents. The modified von-Mises yield criterion considering the compressive and tensile strength of masonry constituents separately was used for plastic strain and the damage model Oliver et al. (1990) was used for damage strain especially for tensile effects. Numerical results and modes of failure are compared with experimental data.

*Bilge Doran: doran@yildiz.edu.tr; doranbilge@gmail.com

\section{Giriş}

Kültürel miras olarak değerlendirilen tarihi yapılar, ülkelerin geçmişi ile bağını kuran, kültür mirasının göstergesi olarak çok önemli bir işleve sahip olan ve geleceğe güvenle aktarılması gereken değerlerdir. $\mathrm{Bu}$ nedenle anılan yapıların, taşıyıcı sistemi, özgün biçimi ve malzemesi ile birlikte tarihi bir belge olarak korunması, istenen ve zorunlu bir durum olacaktır. $\mathrm{Bu}$ tip yapıların özgün özelliklerini kaybetmeden varlıklarını sürdürebilmeleri için yapılacak olan herhangi bir müdahale kararından önce yapının davranışının doğru olarak saptanması gerekir. Tarihi yapıların korunması, onarılması ve güçlendirilmesi kapsamında yapıya ait özgün malzemelerin karakteristik özelliklerine uygun, benzer malzemelerin üretimi ve kullanımına ihtiyaç duyulmaktadır [1-9]. Tarihi yapılarda kullanılacak malzeme özelliklerinin mevcut malzemelerle uyumunun tam olarak tespit edilmesi gerekir. Tarihi yapılardaki harçları incelemek, harç karakterleri ve o dönemin yapım teknikleriyle ilgili önemli bilgiler vermektedir. Tarihi harçların kompozisyonunun belirlenmesi, koruma çalışmalarında verilecek kararlar açısından önemli bir veridir. Tarihi yapılarda kullanımına sık rastlanan kalın harçların, yapıda önemli bir çatlak durumu oluşturmadan zemin oturmalarına izin verdiği, dolayısıyla yapının uzun ömrü boyunca oluşan olası gerilmelere karşı koyabilmede çok uygun olduğu belirlenmiștir. Orijinal harçların detaylı incelenmesi ile fiziksel, kimyasal ve mekanik özelliklerinin tanımlanmasıyla, yeni onarım harçları aynı karakteristik özellikler ile hazırlanabilecektir [10]. Bu bağlamda yapıların özgün malzemelerinin doğru saptanması ve onarımlarında, bu özgünlüğü zedelemeyecek yeni malzemelerin kullanımı büyük önem kazanmaktadır $[3,4,6,11,12]$. Özgün malzeme özelliklerin tespit edilmesi, yapının özgün malzemeleri ile yapıya eklenen yeni malzemelerin uyumu ve bütünleşmesi, sağlıklı bir restorasyon çalışmasının gerçekleştirilebilmesi için temel adımlardandır.

Tarihi yapılarda en yaygın harç çeşidi kireç harcıdır [13]. Bu yapılarda tarihsel gelişim boyunca harç malzemesinin iyileştirilmesi için uğraşılmış, karışım malzemesi olarak kireç, puzolan, pişirilip ögütülmüş kil, taş tozları, tuğla ile kiremit parçacıkları ve tozları kullanılmıştır [14]. Kireç harçları, yapıda oluşabilecek farklı oturmalara ya da $1 S 1$ ve nem değişikliklerinden kaynaklanan hareketlere karşı kolaylıkla uyum sağlayabilmektedir. 19. yüzyılın sonlarında bu harçlar yerini çimento esaslı harçlara bırakmıştır. Bu durumun en önemli nedeni çimento bağlayıcıların kireç bağlayıcılara göre 
daha çabuk sertleşmesi ve hızlı dayanım kazanmasıdır. Ancak, koruma amaçlı yapilan uygulamalarda kullanılan çimento esaslı harçlarda gözlemlenen uyuşmazlık probleminden ötürü, kireç esaslı ürünlerin kullanımı yeniden ortaya çıkmıştır. Kireç esaslı harçlar, koruma uygulamalarında mevcut antik binalardaki malzemelerle fiziksel, kimyasal ve mekanik olarak daha iyi uyum göstermektedir. Bu amaçla kireç esaslı harçların özelliklerini iyileştirme konusunda çalışmalar yapılmaktadır $[15,16]$. Kireç harcının içerisinde yüzey alanı büyük puzolan kullanımı ve karışıma alçı eklenmesi gibi iyileștirme yöntemleri, harçların sertleșme süresini hızlandırarak daha büyük basınç dayanımına sahip olmalarını sağlamaktadır [17]. Kireç harçlarının özelliklerinin iyileştirilmesinde puzolanik katkılar [18, 19] ile organik maddelerin [20] kullanıldığı yönünde çalışmalara rastlanmaktadır.

Çeşitli tuğla/taş elemanlardan (yığma birim) ve farklı içeriklerde harç (bağlayıcı) malzemesiden oluşan yığma duvarlarda, zayıf bölgede olan ve kompozit yapıda olan malzeme harçtır. Yığma yapıların karmaşık mekanik davranışları, büyük ölçüde yapı malzemelerinin kompozit niteliğine bağlıdır. Yığma birimlerin boyutları, derzlerin kalınlıkları, yığma birim ve harçların malzeme özellikleri, duvarın örgü biçimi, yapım işçiliği gibi çok sayıda faktör, yığma yapıların davranışını karmaşık hale getirmektedir. Bu doğrultuda yığma yapının hassas olarak tanımlanması, bir grup deneysel çalışma ile mümkün olmaktadır. Yığmanın davranışındaki bu karmaşıklık durumu, yapıların simülasyonu için yapılan sayısal modelleme çalışmaları için de güçlük teşkil etmektedir. Yığmanın davranışındaki belirsizlik ve karmaşıklık durumunu yansıtmak amacıyla yapılan sayısal modelleme çalışmalarında farklı modelleme teknikleri ve malzeme modelleri kullanıldığı görülmüştür. Yapının geometrik boyutlarını, mesnetlerin ve taşıyıcı sistem elemanlarının birleşim noktalarının hareket yeteneklerini ve serbestlik derecesini, yapı üzerine etki eden yükleri göz önüne alarak, yapının tanımlanması işlemine sayısal modelleme denir. Mevcut yı̆̆ma yapıların/birimlerin değerlendirme ve güçlendirme teknikleri için gerçek davranışı simüle eden birçok sayısal modelleme teknikleri önerilmektedir.

$\mathrm{Bu}$ çalışma ile, tarihi yığma duvarların üç boyutlu doğrusal olmayan sonlu elemanlar yöntemi ile çözümü için özgün malzeme özelliklerini dikkate alan bir bünyesel modelleme tekniği ayrıntılı olarak tarif edilmiş ve başarı ile uygulanmiştır.

\section{Sayısal ve Bünyesel Modelleme Teknikleri}

Yapı malzemesinin mekanik özellikleri hakkında yapılan kabuller, doğrusal elastik davranıș gösteren homojen ve izotrop malzemelerde diferansiyel eleman olarak da bilinen, malzeme modelini oluşturan malzemenin çok küçük bir parçasının davranışına göre belirlenir. Beton, betonarme, yığma, harç ve diğer kompozit malzemeler de modelleme yaklaşımlarında genel olarak homojen ve izotrop olarak kabul edilmektedirler. Gerçekte bu malzemeler heterojen bir yapıdadırlar ve yön bağımlı davranış gösterirler. Malzeme modellerinde, yapı malzemesinin gerilme-birim şekil değiștirme özellikleri göz önüne alınır. $\mathrm{Bu}$ tür malzemeleri homojen ve izotrop bir yapı olarak modellemek için gerilme-birim şekil değiştirme özelliklerinin malzeme bünyesindeki en büyük heterojenliği temsil eden kısmın birkaç katı kadar olan bir bölgede belirlenmesi gereklidir. Kusursuz bir sayısal model oluşturmak için malzeme davranışı ve elemanların bireysel 
davranışının çok iyi etüt edilmesi şarttır [21].

Beton, harç, seramik, tuğla gibi yarı gevrek malzemelerin belirgin bir özelliği göçme durumunun, kademeli çatlak büyümesi süreci sonucu oluşmasıdır. Bu süreci modellemek için betonda kullanılan bir takım malzeme modelleri yığma birimler için de kullanılmıștır. Yığma yapılarda göçme mekanizmasının açıklanması için kullanılan 'düzgün yayılı çatlak modeli'nde, çatlakların etkisi tüm elemana yayılarak eleman rijitlik matrisine yansitılır. Önceleri betonarme yapılardaki çatlakları simule etmek için kullanılmış olan düzgün yayılı çatlak modeli, yığma birimlerin benzer yarı gevrek davranış gösterdiği anlaşıldığında yığma analizleri için de kullanılmıştır [22].



a.

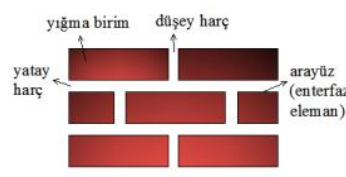

b.

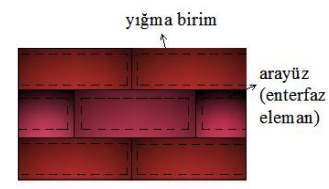

c.
Şekil 1. Modelleme yaklaşımları a) Makro modelleme b) Detaylı mikro modelleme c) Basitleștirilmiş mikro modelleme

Literatürde, yığma duvarların düşey ve yatay yükler altında davranışını araştıran birçok analitik çalışma yer almakla beraber, önerilen sayısal modeller özellikle doğrusal olmayan davranışı belirleyecek malzeme parametreleri açısından önemli belirsizlikler içermektedir. Modelleme tekniği olarak genel anlamda, makro, detaylı mikro ve basitleștirilmiş mikro modelleme yaklaşımları tercih edilmektedir (Şekil 1). Makro modelleme yönteminde yığma birimler ve dügüm noktaları arasında bir ayırıcı eleman olmadan homojen bir yapı olarak modellenmektedir. Bu yöntemde tuğla ve harç beraber modelleneceği için, malzeme parametreleri farklı bir teknikle birleştirilerek dikkate alınmaktadır. Page [23] ve Ghosh [24], makro modellemenin düşük değerdeki gerilme değerlerinde şekil değiștirmeleri yeterli șekilde tahmin ettiğini, yüksek gerilme değerlerinde aşırı gerilme dağılımları oluştuğu zaman yetersiz kaldığını belirtmişlerdir. Detaylı mikro modelleme yönteminde tuğla, harç ve tuğla-harç arasındaki yüzey ayrı ayrı modellenerek her bir malzemenin elastisite modülü, poisson oranı ve plastik özellikleri dikkate alınır. Mikro modellemede tanımlanan ara yüzey elemanların çeşitli amaçları vardır. Detaylı mikro modellemede, harcın derzlerinde oluşan kompozit davranıșın bir kısmını hesaba katmak için harç ve yığma birim arasındaki temas yüzeyi kullanılır. Enterfaz ya da arayüz olarak da adlandırılan bağlantı elemanları, malzemelerin mekanik özelliklerini modele yansıtırken en fazla çaba gerektiren kısımlardır [22]. Bağlantı elemanları tanımında yapay/hayali bir başlangıç rijitliği kullanılarak potansiyel bir çatlak düzlemi olușturulur. Bu rijitliğin ölçülen bir değeri yoktur, davranışı tahmin etmek için herhangi bir değer seçilebilmektedir. $\mathrm{Bu}$ tanım, yığma birim, harç ve ara yüzeyin ortak hareketine olanak sağlar [25]. Basitleștirilmiş mikro modellemede tuğla/taş birimler sürekli elemanlarla modellenirken, harç derzleri ve tuğlaharç ara yüzeyleri bütün olarak süreksiz elemanlarla modellenir [26]. Basitleștirilmiş mikro modelleme tekniğinde ara yüzey elemanlar, harç, yığma birim-harç bağlantısı ve yığma birimin bir kısmındaki karmaşık etkileşimini yansıtarak, derzlerin davranışını bütünüyle hesaba katar [22]. Basitleştirilmiş mikro modelleme yöntemi detaylı mikro modellemeye 
göre, sayısal değerlerde ve hesaplarda önemli oranda değişiklik olmaksızın model anlamında geometrik karışıklığı azaltır. Bu bakımdan, sayısal davranışın bütünüyle anlaşılması bakımından önemli bir avantaja sahiptir. Bu yaklaşımda, her bir derz elemanı hem harcl, hem iki tane harç-tuğla ara yüzeyini kapsamaktadır. Bu elemanlar, potansiyel çatlak, kayma ve kırılma düzlemlerini yansıtmaktadır. $\mathrm{Bu}$ durumda, yığmayı potansiyel kayma çizgileriyle bağlı elastik birimler olarak göz önüne almak mümkün olmaktadır [25].

\section{3. Önerilen Modelleme Tekniği}

Günümüz hesaplama olanakları ve yöntemleri karmaşık geometri ve homojen olmayan malzeme özellikleri için sonlu elemanlar yöntemini en uygun analiz yöntemi haline getirmektedir [27]. Sayısal modelleme yaklaşımının temel amacı, malzemenin hasar ve göçme durumunu sayısal olarak ifade etmektir. Burada problem doğrusal olmadığı için anılan yaklaşımda malzeme için doğrusal olmayan bünyesel davranış modellerinin kullanılması gerekmektedir. Malzemenin doğrusal olmayan davranışı, plastisite veya hasar mekaniği esaslı bünye bağıntıları ile göz önüne alınır. Diğer taraftan malzeme modelinin uygunluğu, yapıya ilişkin göçme modlarını yeterince gerçek bir şekilde tahmin etme yeteneğiyle değerlendirilebilir.

Bu çalışmada 111M568 no.lu Tübitak projesi kapsamında; tarihi yapılarda kullanılan malzemelerin özelliklerinin saptanması, onarım ve güçlendirme ile restorasyon çalışmalarında kullanılacak olan özgün malzemelerin üretilmesi için bir dizi deneysel çalışma sonuçları dikkate alınarak uygun malzeme modeli araştırılmıştır. Özgün malzemeler kullanılarak üretilen 6 farklı duvar numunesinin düșey yükler ile kademeli olarak artırılan yatay yükler altında davranışları irdelenmiş, yük-yer değiştirme ilişkileri belirlenmiştir. Deney duvarlarına ait gerçek davranışa en yakın sonuçları verecek sayısal modelleme tekniği olarak basitleştirilmiş mikro modelleme tekniği, bünyesel modelleme tekniği olarak ise plastik model ile beraber izotropik hasar modeli seçilmiştir. Hasar mekaniğindeki şekil değiștirme artışı Oliver [28] modeli kullanılarak ifade edilirken, plastik şekil değiștirme geliştirilmiş von-Mises plastisite modeliyle ifade edilmiștir. LUSAS [29] sonlu eleman analiz programında malzeme kriteri olarak tanımlanmıș olan geliștirilmiş von-Mises akma kriteri, kırılma yüzeyini belirlemek üzere çekme ve basınç gerilme değerlerini ayrı ayrı dikkate almaktadır $\left(f_{c} \neq f_{t}\right)$. Bu nedenle, tuğla ve harç gibi çekme ve basınç dayanımlarının eşit olmadığı malzemelerde bu kriter kullanılabilmektedir (Şekil 2).

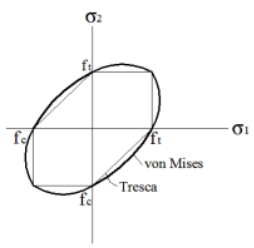

a.

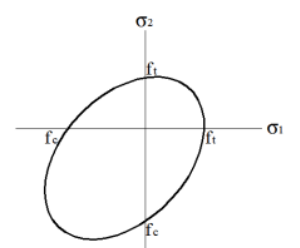

b.
Şekil 2. a. von-Mises akma kriteri, b. Geliștirilmiş von-Mises akma kriteri

Malzemenin elasto-plastik davranışı, elastik bölgenin aşılıp belli bir gerilme değerine ulaștıktan sonra plastik șekil değiştirme gösterdiği davranış olarak tanımlanır. Gerilme-birim şekil değiştirme eğrisinde başlangıçta doğrusal ilişkiye sahip malzeme davranışı, gerilmelerin "hasar eşiği" olarak adlandırılan gerilme değerlerini aştığında, elastisite modülü değerinin azaltılması ile tanımlanır [30]. Plastik şekil değiştirmenin başlangıcı bir akma kriteri yardımı ile belirlenmekte olup, akma sonrasında oluşan şekil değiştirme malzeme dayanımının büyük 
ölçüde düşüşü sonucu ortaya çıkmaktadır. Hasar mekaniği, mikro çatlak ve mikro boşlukların ilerlemesine bağlı malzeme bütünlüğü kaybını tanımlayan bir teoridir. Esas amaç, bünyesel yapıda meydana gelen çatlaklar nedeniyle değişen durumun, makro ölçekte gözlenen malzeme dayanımında yol açacağı zafiyeti matematiksel olarak ifade etmektir. Kachanov [31] un akma kopması bağlamında bahsettiği hasar kavramı, daha sonra birçok araştırmacl tarafından incelenmiștir. Hasar sonrası çatlak oluşumuyla birlikte malzemenin ve dolayısıyla yapının rijitliğinde bir azalma olduğu bilinmektedir [32]. Tuğla ve harç gibi yarı gevrek malzemelerde mikro çatlaklar, hasar değişkenlerinin artan değerleriyle ifade edilmiştir. Bu değişkenler, akma yüzeyinin ve elastik rijitlik bozunmasının gelişimini denetler. Elastik hasar mekaniğinde, malzemenin elastisite modülü hasarın ilerlemesiyle gittikçe azalır [33]. Ayrıca, bu hasar değişkenleri mikro çatlakların oluşması için gerekli kopma enerjisinin bir ifadesidir. Yığmadaki hasarın harçtaki çekme çatlaklarının başlangıcı ve artışına bağlı olduğu varsayılmaktadır [34].

Hasar mekaniğindeki temel yaklașım, herhangi bir taşıyıcı elemanın içyapıdaki kusurlarının da bir yansıması olan başlangıç elastisite modülü değerinin belli bir hasar eșiğinin aşılmasıyla birlikte kademeli olarak azaltılması varsayımına dayanmaktadır (Şekil 3). Bu azaltma işlemi, yükleme ve şekil değiștirmeler ile birlikte artan, değeri 0 ila 1 arasında olan bir hasar değişkeni (d) yardımıyla analizlerde dikkate alınmaktadır [28, 35]. Hasar değişkeni, fiziksel olarak temsili bir eleman hacmini kesen bir düzlem üzerinde yer alan mikro-çatlak ve boşlukların yüzeysel yoğunluğu olarak tanımlanır. Buradaki temsili boyut, genel olarak malzeme bünyesindeki en büyük heterojenliği ifade eden parçacığın boyutunun 3 ila 5 katıdır. Hasar gelişimini belirleyen en önemli değişken $d$, hasar yüzdesi olarak düşünülebilir ve beton, yığma gibi malzemelerde çatlakların ilerlemesi için gerekli olan $G_{f}=G\left(d_{\max }, E_{0}\right)$ "kırılma enerjisi" cinsinden ifade edilebilir. Kırılma enerjisi, birim alanda bir çatlak yüzeyinin oluşması için gerekli enerji olarak tanımlanır. Bu çatlaklar eksenel çekme, düzlemsel kayma ve düzlem dışı kayma biçimde gelişebilirler. Ancak bu tür çatlaklar için kırılma enerjilerinin ölçülmesi özellikle taneli ve gevrek malzemelerde oldukça güçtür. Beton benzeri malzemeler çekmede yumuşama özelliği gösteren malzeme olarak modellenir [36, 37].

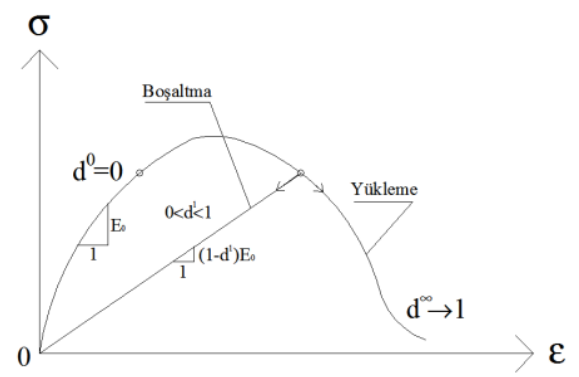

Şekil 3. Hasar mekaniğinde eksenel gerilmebirim şekil değiştirme diyagramı [28]

Artan bir derecede yumușama davranıșı gösteren malzemelerde kırılmayı izah etmek için Köksal ve Karakoç [35], kırılma enerjisini izotropik hasar modeli kullanarak Denklem 1'deki şekilde hesaplamıșlardır:

$G_{f}=k l_{c h} \sigma_{\max }^{2} / E_{0}$

Burada $k$ yaklaşık olarak 5,16 alınabilir. Daha küçük karakteristik uzunluk değerleri malzemeyi daha gevrek hale getirir unsuru göz önüne alınarak; maksimum agrega boyutunun 3 ila 5 katı olacak şekilde farklı karakteristik uzunluklar kullanılarak kırılma enerjisi değerleri hesaplanabilir. $G_{f}$ ifadesinde tuğla için, ( $b$ : brick); sanal birleşim bölgesi malzemesi için (fm: fictitious material) olmak üzere:

$G_{f_{f_{m}}}=15,48 d_{\max } f_{t}^{2} / E_{0}$ 
$G_{f_{b}}=25,8 d_{\max } f_{t}^{2} / E_{0}$

şeklinde göz önüne alınmıştır. Oliver hasar modelinde çok eksenli basınç altındaki izotropik homojen bir malzemenin davranışını ifade etmek için kullanılan 3 tane malzeme parametresi bulunmaktadır. Bunlardan ilki, "başlangıç hasar eşiği" $\tau^{*}$; elastik olmayan davranışın başlangıcını, diğer bir ifadeyle çekme çatlaklarının başlangıcını ifade eder (Denklem 4). Elasto-plastik malzeme analizlerinde başlangıç akma gerilmesine benzer bir fonksiyon olarak göz önüne alınır. Hasar modeli için tanımlanan ikinci parametre olan $A$ değeri, doğrusal olmayan sonlu eleman analizinde elde edilen sonuçların seçilen ağ boyutuna bağlı olmasını önlemek amacıyla kullanılan bir malzeme parametresidir (Denklem 5). Hasar, çatlak genişlemesi ile ortaya çıkan ve ilerleyen bir mekanizma olduğundan kırılma enerjisine bağlı olarak ifade edilmektedir. Hasar modeli için tanımlanan diğer bir malzeme parametresi ise, malzemenin basınç dayanımı ile çekme dayanımı arasındaki oranı ile ifade eden $\eta$ değeridir (Denklem 7).

$$
\begin{gathered}
\tau^{*}=f_{t} / \sqrt{E_{0}} \\
A=\left(\frac{G_{f} E_{0}}{h f_{t}^{2}}-\frac{1}{2}\right)^{-1} \geq 0
\end{gathered}
$$

Burada $h$ değeri birim boyuta göre Denklem 6'daki şekilde hesaplanır:

$h=\sqrt[3]{h_{x} h_{y} h_{z}}$

$\eta=f_{c} / f_{t}$

Sayısal modelleme çalışmasında, yığma duvarlar modellenirken tuğla ve sanal birleşim bölgesi malzemesi için LUSAS [29] sonlu eleman analiz programında tanımlanmıș olan sekiz düğüm noktalı altı yüzlü eleman (HX8M) 3 boyutlu eleman kullanılmıştır (Şekil 4).

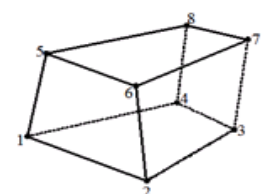

Şekil 4. HX8M katı eleman

Lotfi ve Shing [38], Lourenço ve Rots [39] ile Mehrabi ve Shing [40] tarafından geliştirilen modelleme yaklaşımı, tuğla elemanlarda doğrusal elastik dağılımın devam ederken, enterfaz elemanlarda elastik olmayan davranışların toplanması/yoğunlaşması kabulüne dayanır. Bu çalışmada, harç derzleri ve harç-yığma birim arasındaki enterfaz bölgeyi tanımlamak amacıyla Şekil 5'te görülen "sanal birleșim bölgesi malzemesi" önerilmiştir. Deneysel duvarlara ait doğrusal olmayan sonlu eleman analizlerinin ilk sonuçlarına göre, modellemede harç malzemesi için ölçülen elastisite modülü değerine göre çok daha küçük bir değer kullanıldığında, harç enterfaz bölgesini tanımlamak için kullanılan herhangi bir sıfır kalınlıklı eleman kullanmadan sonuçların deneysel sonuçlarla uyumlu olduğu görülmüștür. $\mathrm{Bu}$ sonuç, bu bölgenin çok zayıf özellikte olduğunu ve deney sırasinda eksenel yük uygulandıktan sonra -basınç dayanımı düşük olduğu için- oldukça hasar gördüğü şeklinde açıklanabilir. Deney sırasında yatay yükün uygulanmasından hemen önce, tanımlanan sanal birleşim bölgesi malzemesinin başlangıç rijitliği değerlerinin önemli ölçüde azaldığ sonucuna varılabilir.

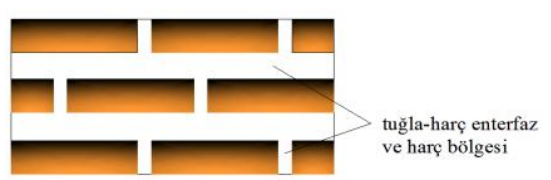

Şekil 5. Yığma duvar için önerilen sanal birleşim bölgesi tanımı

\section{Sayısal İrdelemeler}

Çalışma kapsamında bahsedilen projenin amacı; tarihi yapıların onarım 
ve güçlendirilmesinde kullanılacak uygun malzemelerin kullanılması amaciyla, ülkemizde bulunan tarihi yapılardan alınan numunelerle özgün malzeme özelliklerinin belirlenmesi, bu doğrultuda yeni harç malzemesi üretimleri gerçekleştirerek yeni malzemelerle oluşturulacak olan yığma duvarların düzlem içi yükler etkisindeki davranışlarının araştırılmasıdır. Proje kapsaminda tarihi binalardan alınan numunelere göre belirlenen basınç dayanımı değerleri tuğla için 10,2-10,3 $\mathrm{MPa}$; harç için 1,1-3,9 $\mathrm{MPa}$ arasında değişmektedir. Yerinde yapılan ölçümlerden yatay derzlerdeki harç kalınlıklarının 4,5-5,5 cm arasında değiştiği tespit edilmiştir. Tarihi yapılardan alınan harçlarda kullanılan agregaların tane boyutu dağılımının belirlenmesi için elek analizi yapılmış, buna göre agregaların maksimum tane boyutunun apsidal yapı kalıntısında ortalama $16 \mathrm{~mm}$; Koca Ragıp Paşa Kütüphanesi'nde ortalama $4 \mathrm{~mm}$ olduğu belirlenmiştir. Deneysel çalışmada oluşturulacak yığma duvarlarda seçilecek harcın bileşimi, kireç:agrega oranı ve yatay derz kalınlıkları belirlemek için bir literatür araştırması yapılmış, bu araștırma ve yerinde yapılan ölçümler dikkate alınarak farklı harç içerikleri oluşturulmuştur (Tablo 1). Yatay derz kalınlığı ise özellikle Bizans ve Roma döneminde pek çok tarihi eserde kullanılmış olan yatay derz kalınlığı dikkate alınarak 40 mm olarak seçilmiştir.

Tablo 1. Proje kapsamında üretilen harçların sınıflandırılması

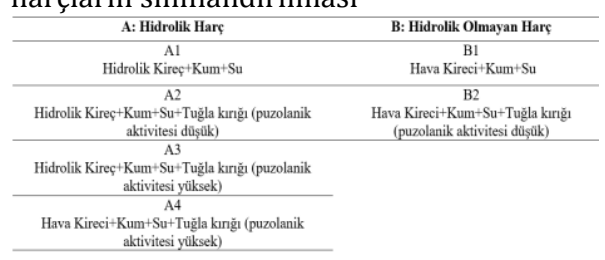

Çalışmada kullanılan yığma duvarlar, üretici firma tarafından temin edilen boyutları 180x50x80 mm olan harman tuğlaları ve Tablo 1'de içerikleri verilen harçlarla birlikte $860 \times 860 \times 80 \mathrm{~mm}$ boyutlarında hazırlanmıştır. Bu makale kapsamında yalnızca hava kireci ile oluşturulmuş olan A4, B1 ve B2 harçları ile üretilmiş duvarlar göz önüne alınacaktır. Anılan harçların karıșım oranları Tablo 2'de verilmiștir. Deney kapsamında uygulanan düşey yükün duvara üniform olarak dağılması amacıyla çelik bir levha kullanılmış ve yük, 200 ton kapasiteli düșey hidrolik jack ile $25 \mathrm{kN}$ değerinde uygulanmıştır. Yatay yük değeri ise $5 \mathrm{kN}$ olarak uygulanmaya başlanmış ve yer değiştirme değeri okunduktan sonra kademeli olarak arttırılmıştır $(\Delta P=5$ $\mathrm{kN}$ ). Deney düzeneği Şekil 6'da, deney duvarlarının boyutları ve yükleme durumu ile yükleme durumu ve yer değiştirmeleri ölçmek kullanılan 4 adet LVDT (Linear Variable Differential Transformer) yerleşimi ise Şekil 7'de görülmektedir. Deney duvarında kullanılan harman tuğlasında TS EN 772-1'e [41] uygun olarak hazırlanan numunelerde tek eksenli basınç deneyi yapılarak basınç dayanımları belirlenmiştir.

Tablo 2. A4, B1 ve B2 harçlarının karışım oranları
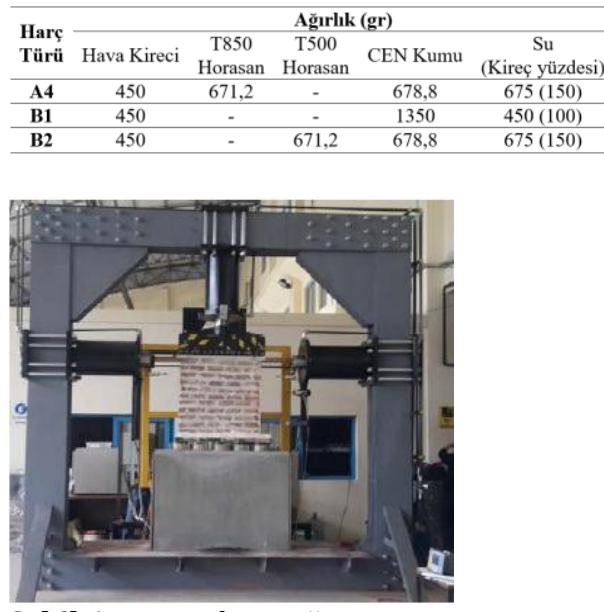

Şekil 6. Deney düzeneği 


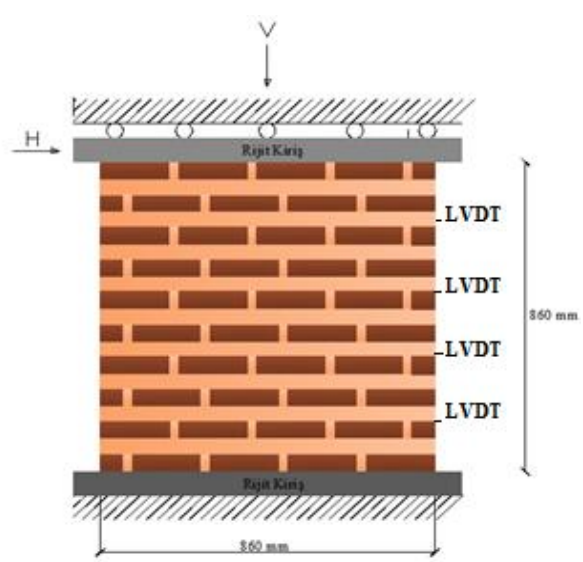

Şekil 7. Deney duvarının boyutları ve yükleme durumu

Harçların eğilme ve basınç dayanımları ise $40 \times 40 \times 160 \mathrm{~mm}$ boyutlarındaki prizmatik numunelerde TS EN 101511[42] esaslarina uygun olarak ölçülmüştür. Harçların elastisite modüllerinin belirlenmesi için TS EN 13286-43 [43] esasları dikkate alınmıştır. Ayrıca kireç harçlarının Poisson oranlarını belirleyebilmek için $30 \times 30 \times 5 \mathrm{~cm}$ boyutlarında prizmatik harç numuneler üretilmiş ve levha gibi yüklenerek tek eksenli basınç deneyine tâbi tutulmuştur. Bu çalışmada, deney duvarına ait sayısal model için önerilen bünye denklemlerinde tuğla için ölçülen basınç dayanımı, elastisite modülü ile Poisson oranı değerleri kullanılmıștır. Anılan mekanik parametreler dikkate alınarak hesaplanan hasar parametreleri Tablo 3'te gösterilmiştir. Sanal birleşim bölgesi malzemesi için göz önüne alınan elastisite modülü, poisson oranı, basınç ve eğilmede çekme dayanımları değerleri ile bu parametreler dikkate alınarak hesaplanan hasar parametreleri ise Tablo 4'te verilmiştir.

Tablo 3. Sayısal modellerde kullanılan mekanik parametreler (tuğla için)

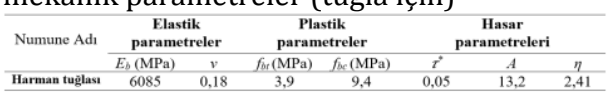

Tablo 4. Sayısal modellerde kullanılan mekanik parametreler (sanal birleşim bölgesi malzemesi için)

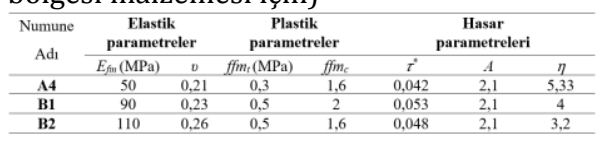

Duvar numunelerinde deney sonucunda gözlenen hasarlar, yığma birimlerde gelişmesi muhtemel lokal hasar tipleriyle ile açıklanmıştır. Deney sonucu hasarlı duvarların hem fotoğrafları, hem de oluşan çatlakların ölçülüp Autocad [44] programı ile çizilmiş şekilleri görülmektedir. Autocad çiziminde kullanılan çatlak genişlikleri değerleri Şekil 8'de gösterilmiştir [45].

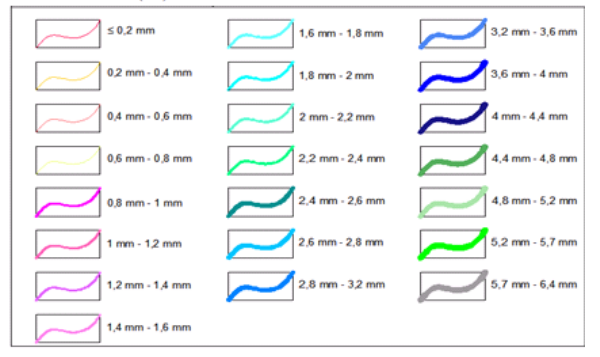

Şekil 8. Çatlak genişlik değerleri

Deney duvarlarında oluşan çatlakların her bir düğüm noktasındaki kayma gerilmesi değerleri sonucu oluşan şekil değiştirmeler sonucunda oluştuğu açııtır. Bu bağlamda deney duvarları için sayısal analiz sonucu düğüm noktalarında oluşan $\sigma_{x}, \sigma_{y}$ ve $\tau_{x y}$ kayma gerilmeleri değerlerine göre Denklem 8 kullanılarak $\theta$ kayma açıları hesaplanmıștır. Şekil 9'da, düzlem gerilme durumunda bir elemanın $X$ ve $Y$ düzleminde kayma açısı değeri ve kayma gerilmeleri görülmektedir [45]:

$\tan \theta=\frac{2 \tau_{x y}}{\sigma_{x}-\sigma_{y}}$ 


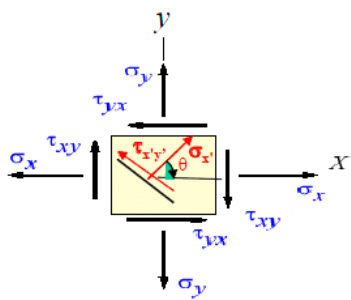

Şekil 9. Düzlem gerilme elemanında kayma gerilmeleri ve kayma açısı

Denklem 8'e göre hesaplanan açlardan, deney duvarlarının mekanizma durumunda oluşan çatlak şeklini belirlediği düşünülen değerlerin oluştuğu dügüm noktaları işaretlenmiştir (Şekil 13, 17, 21). İşaretlenen düğüm noktaları duvar bütünü kapsamında incelendiğinde, yatay yükün model duvarlara uygulanma noktasının bitiminden itibaren (üstten iki tuğla bir harç yüksekliği) duvarın alt ucuna kadar devam eden yatay derz ve düşey derzlerin birleştiği yerlerde yoğunlaşan kayma hareketleri gözlemlenmiştir. $\mathrm{Bu}$ değerlerin büyüklüklerine göre çatlak boyutları değișmiştir.

\subsection{A4D}

A4D numunesinde yatay yük değeri 25 kN'a ulaștığında, oluşan yer değiștirme değeri 26,35 mm olmuştur (Şekil 10).

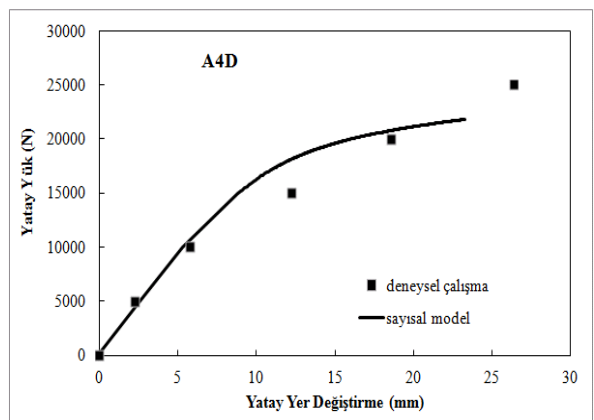

Şekil 10. Deneysel ve sayısal model yük-yer değiştirme eğrileri

Deney sonucu duvarın alttan üçüncü yatay harç ve alt kısmındaki düşey harç bölgesinde ise çekme gerilmesi yığılmasından dolayı oluşan çatlak diğer bölgelerdekine nazaran biraz daha geniştir (Şekil 11).

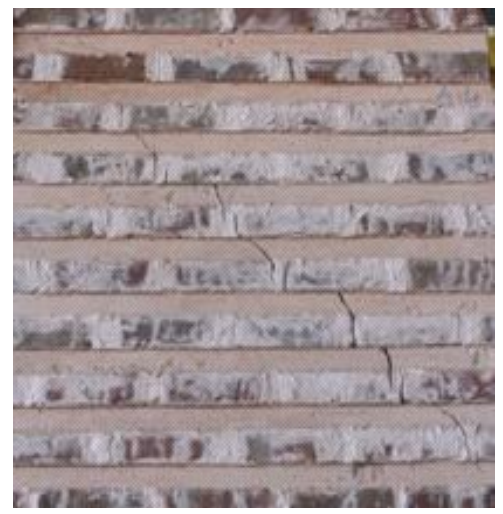

Şekil 11. Deney sonucu mekanizma durumu

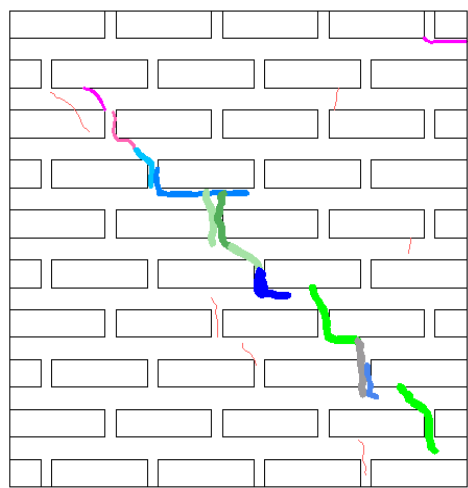

Şekil 12. Duvarda oluşan çatlak şekilleri

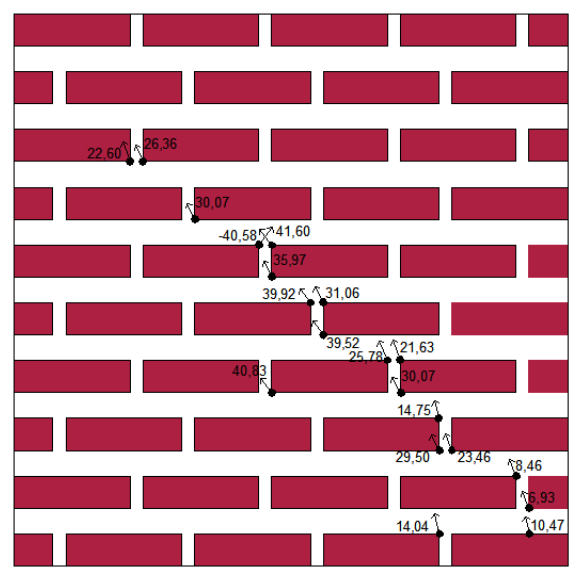

Şekil 13. Sayısal analiz sonucu düğüm noktalarında oluşan kayma açıları 


\subsection{B1D}

Duvara kademeli olarak uygulanan 25 $\mathrm{kN}$ yatay yük bu değerinde oluşan yer değiştirme değeri 12,34 mm olmuştur (Şekil 14). Yatay derzlerde önemli miktarda ezilme görülmüştür. Üretiminde hava kireci kullanılan harç ile üretilen bu duvarın, bütün numuneler arasında en küçük basınç dayanımına sahip olması nedeniyle, yatay yük uygulamaya başlanmadan önce düşey yük etkisiyle duvarda harç birimde ezilmeler meydana gelmiştir.

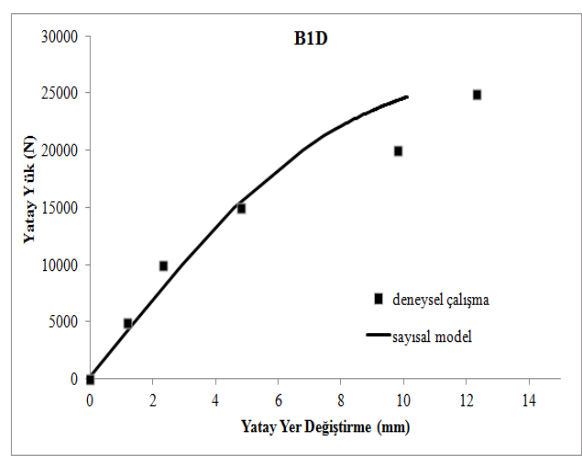

Şekil 14. Deneysel ve sayısal model yük-yer değiştirme eğrileri

Duvarın 2., 3. ve 4. yatay harç sıralarında boydan boya ezilmeler oluşmuştur.

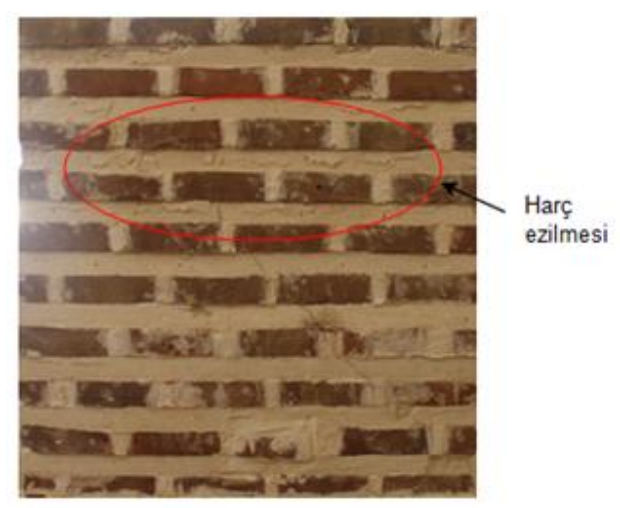

Şekil 15. Deney sonucu mekanizma durumu

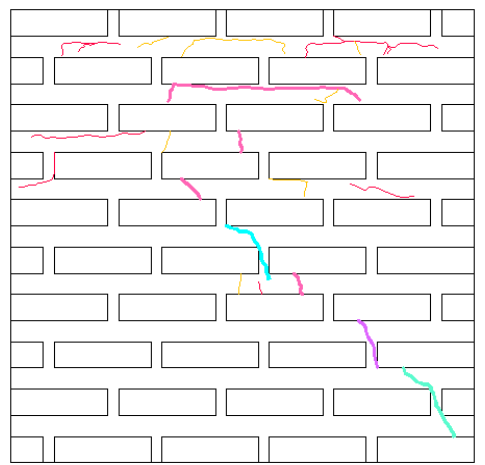

Şekil 16. Duvarda oluşan çatlak şekilleri

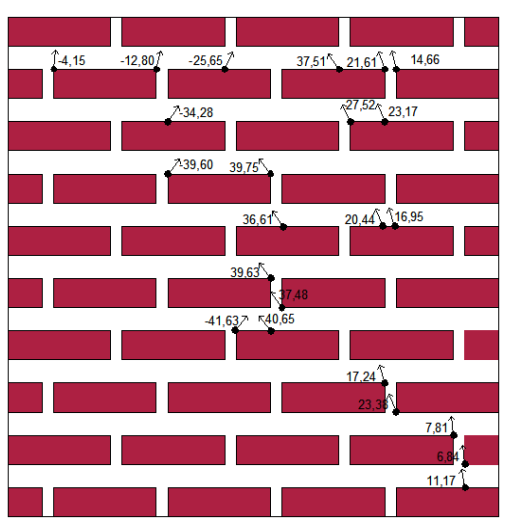

Şekil 17. Sayısal analiz sonucu düğüm noktalarında oluşan kayma açıları

\subsection{B2D}

B2D numunesinde yatay yük $25 \mathrm{kN}$ 'a ulaştığında, yatay harçlarda oluşan basınç çatlakları kritik değerlere ulaşmış ve deney sonlandırılmıștır. Bu değerde oluşan yer değiștirme değeri 4,6 mm olmuștur (Şekil 18). B2D duvarında, yük etkisiyle oluşan çatlaklar diğer duvar numunelerinde gözlemlendiği gibi duvarın sol üst kısmından sağ alt ucuna kadar diyagonal çatlak şeklinde devam etmektedir. $\mathrm{Bu}$ duvarda da B1D duvarında görüldüğü gibi düșey yük altında harç ezilmeleri gözlemlenmiştir (Şekil 19). B1D ve B2D duvarlarında karşılaşılan durum, hava kireci ile harç yapılırken mutlaka katkı (horasan ilavesi) kullanılması gerektiğini göstermektedir. 


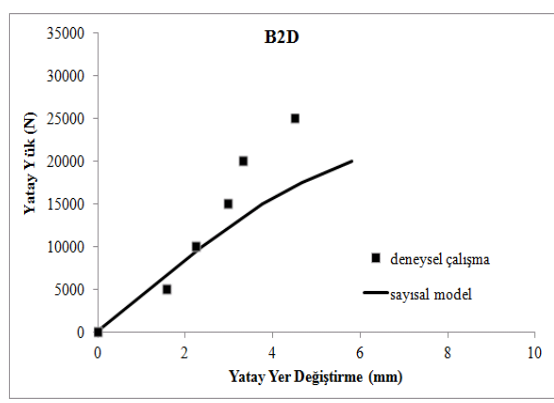

Şekil 18. Deneysel ve sayısal model yük-yer değiştirme eğrileri

Bu duvarlarda basınç yükü altında ciddi harç ezilmeleri gözlenmiș ve bu durum yatay yüklere karșı yeterli kayma dayanımlarının oluşmasını engellemiştir.

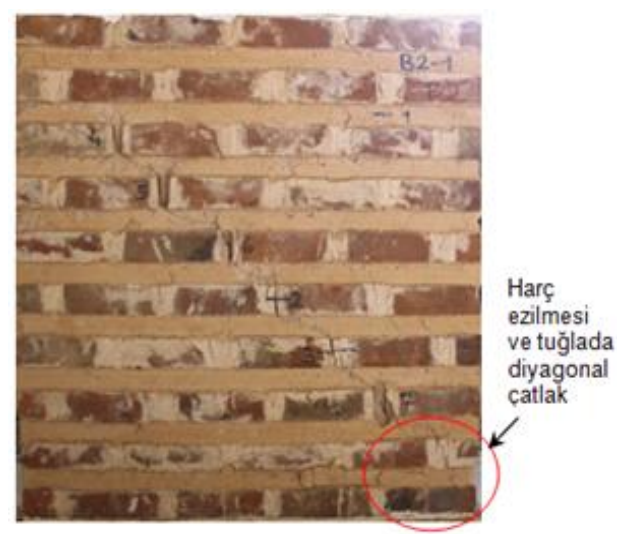

Şekil 19. Deney sonucu mekanizma durumu

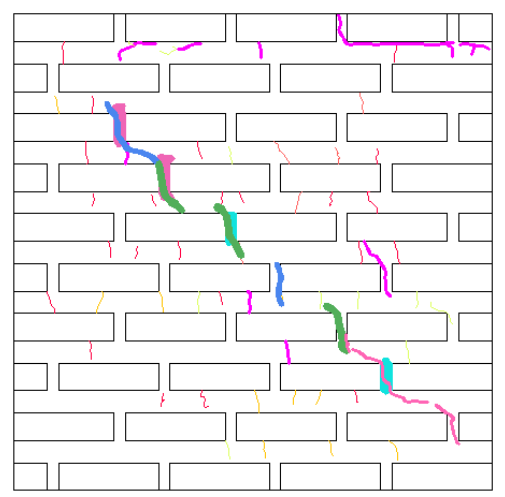

Şekil 20. Duvarda oluşan çatlak şekilleri

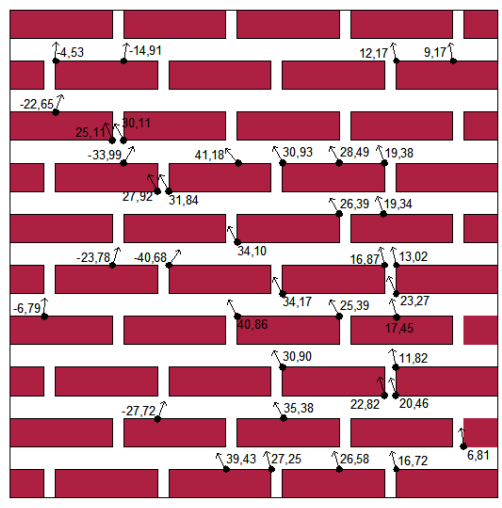

Şekil 21. Sayısal analiz sonucu dügüm noktalarında olușan kayma açıları

\section{Sonuçlar}

Bu çalışmada, sayısal modelleme tekniği olarak basitleştirilmiş mikro modelleme tekniği ve bünyesel modelleme tekniği olarak plastik model ile beraber izotropik hasar modelini dikkate alan bir elasto-plastik hasar modeli önerilmiş, önerilen bu modelleme tekniği ile üç boyutlu doğrusal olmayan sonlu elemanlar analizleri gerçekleştirilmiştir. $111 \mathrm{M} 568$ no.lu Tübitak projesi kapsamında çalıșılan üç örnek duvar için sayısal çözümler deneysel verilerle karşılaştırılmalı olarak verilmiştir. Buna göre aşağıdaki sonuçlara ulaşmak mümkün olmuştur:

1. Hemen hemen tüm duvar numunelerinde beklendiği üzere 45 derecelik basamak şeklinde çatlaklar oluşmuştur. Oluşan çatlakların genişlikleri harcın özelliğine ve davranışına bağlı olarak üç duvarda da değişiklikler göstermiştir; puzolanik aktivitesi yüksek tuğla kırığı ilaveli A4 harcı ile üretilen duvar, hava kireçli katkısız B1 ve puzolanik aktivitesi düşük tuğla kırığı ilaveli B2 harçları ile üretilen duvarlara göre daha sünek bir davranış sergilemiş, B1 ve B2 harçları ile üretilen duvarlar basınç yüklemesi altında özellikle harç kesimlerinde basınç ezilmeleri meydana geldiğinden artan yatay 
yükler altında gerekli dayanımı sergileyememiştir.

2. Hava kireçli harçlarda puzolanik aktivitesi yüksek olan horasan katkılı A4 harcı hava kireçli katkısız B1 harcına göre 2 kat, puzolanik aktivite göstermeyen horasan katkılı B2 harcına göre 1,6 kat yüksek basınç dayanımı değerlerine sahiptir. Eğilme dayanımı değerlerine bakıldığında ise katkısız B1 harcl 0,5 MPa ile en yüksek değeri, diğer harçlar $0,3 \mathrm{MPa}$ ile katkısız harcın eğilme dayanımına yakın bir değer vermektedir.

3. Puzolanik özellik göstermeyen horasan katkısı elastisite modülü üzerinde oldukça etkili olmuștur. Hem harç hem duvar bazında bu harçlarla oluşturulan duvarlar en düşük elastisite modülü değerlerini vermiştir. Horasan katkılı kireç harcl, suya direnci, mekanik özelliklerinin istenilen düzeylerde oluşu, yapısındaki çözünür tuzların azlığı ve tarihi harç dokusu ile uyumlu olması sebebiyle tarihi eser onarım çalışmalarında kullanılacak ideal harç olarak nitelendirilebilir. Çekme dayanımı yüksek bir malzeme harca eklendiğinde, harç içerisinde donatı şeklinde bir davranış göstererek kayma düzlemini bir arada tutma etkisi gösterir. Bu durum bu şekilde olan harçların basınç dayanımının yüksek olmasını açıklamaktadır.

4. Çalışmada önerilen yaklaşım kullanılarak elde edilmiş olan yatay yük- yer değiştirme diyagramları deneysel verilere oldukça yakın kalmıştır. $\mathrm{Bu}$, tarihi yığma duvarlarda bünyesel modellemede geliştirilmiş von-Mises akma kriteri ve Oliver hasar modelinin birlikte kullanılabileceğini göstermiştir.

5. Sayısal model sonuçlarının incelenmesi ile, elde edilen kırılma modları; çatlak gelişimi ve genişliklerinin deney duvarlarında gözlenen duruma kısmen özdeş olduğu sonucuna varılmıştır.

6. Hasar gören tarihi duvarların onarımı ile ilgili birçok yöntem mevcuttur. $\mathrm{Bu}$ çalışma ile onarım yöntemi olarak aynı harç malzemesinden üretilmiş enjeksiyon malzemesinin kullanılması planlanmış ve bu konu “Enjeksiyon Yöntemi (Grouting) ile Onarılmış Tarihi Tuğla Duvarların Yük Altında Davranışının İncelenmesi" başlıklı bir Tübitak projesi ile halen araştırılmaktadır.

\section{Teşekkür}

Bu çalıșma, TÜBİTAK 1001 Program kodlu 111M568 numaralı projesi ile Yıldız Teknik Üniversitesi Bilimsel Araştırma Projeleri Koordinatörlüğü' nün 2013-05-01-D0P01 numaralı projesi ile desteklenmiştir. Yazarlar, anılan projede emeği geçen tüm araştırmacılara ve özellikle Prof.Dr. Hasan Orhun KÖKSAL ile Prof.Dr. Nabi YÜZER'e teșekkürü bir borç bilir.

\section{Kaynakça}

[1] Torraca, G. 1982. Porous Building Materials, Rome.

[2] Feilden, B. 1982. Conservation of Historic Buildings. UK: Butterworth-Heinemann.

[3] Ashurst, J. 1984. Mortars, Plasters and Renders in Conservation. London, United Kingdom: Ecclesiastical Architects' and Surveyors' Association.

[4] Teutunico, J.M. 1988. A Laboratory Manual for Architectural Conservation. ICCROM Sintesi Grafica, Rome.

[5] Ersen, A. 1990. Koruma Amaçlı Yapı Malzemeleri. İstanbul: İTÜ Mimarlık Fakültesi Restorasyon Anabilim Dalı.

[6] Güleç, A., Ersen, A. 1998. Characterization of Ancient Mortars: Evaluation of Simple and Sophisticated Methods. Journal of 
Architectural Conservation, Cilt. 1, s.56-67. DOI:10.1080/13556207. 1998.10785207

[7] Jokilehto, J. 1999. A History of Architectural Conservation. England: Butterworth Heinemann.

[8] Moropoulou, A., Bakolas, A., Moundoulas, P., Aggelakopoulou, E., Anagnostopoulou, S. 2005. Strength Development and Lime Reaction in Mortars for Repairing Historic Masonries, Cement\&Concrete Composites, Cilt. 27, s.289-294.DOI: 10.1016/j.cemconcomp.2004.02.0 17

[9] Aggelakopoulou, E., Bakolas, A., Moropoulou, A. 2011. Properties of lime metakolin mortars for the restoration of historic masonries, Applied Clay Science, Cilt. 53, s.1519.DOI:10.1016/j.clay.2011.04.005

[10] Candeias, A.E., Nogueira, P., Mirao, J., Silva, A.S., Veiga, R., Casal, M.G., Ribeiro, I., Seruya, A.I. 2006. Characterization of Ancient Mortars: Present Methodology and Future Perspectives. in Proc. Workshop on Chemistry in the Conservation of Cultural Heritage: Present and Future Perspectives, Perugia, Italy.

[11] Aköz, A.H. 2008. Deprem Etkisi Altındaki Tarihi Yığma Yapıların Onarım ve Güçlendirilmesi. İstanbul Teknik Üniversitesi Fen Bilimleri Enstitüsü, Yüksek Lisans Tezi, 137s, İstanbul.

[12] Schueremans, L., Cizer, Ö., Janssensa, E., Serréa, G., Van Balen, K. 2011. Characterization of Repair Mortars for the Assessment of their Compatibility in Restoration Projects: Research and Practice, Construction and Building Materials, Cilt. 25, No. 12, s.43384350.DOI:10.1016/j.conbuildmat.2 011.01.008

[13] Lourenço, P.B, van Hees, R., Fernandes, F., Lubelli, B. 2013.
Characterization and Damage of Brick Masonry, Structural Rehabilitation of Old Buildings, Cilt. 2 , s.109-130. DOI:10.1007/978-3642-39686-1_4

[14] Bayraktar, A. 2006. Tarihi Yapıların Analitik İncelenmesi ve Sismik Güçlendirme Metodları. İstanbul: Beta Basım Yayım, 1. Baskı.

[15] Constantinides, I. 1995. Traditional Lime Plaster: Myths, Preconceptions and the Relevance of Good Practice. The Building Conservation Directory.

[16] Tuncel, E.Y., Polat Pekmezci, I., Pekmezci, B.Y. 2013. PVA ve PP Lif İçeren Kireç Harçlarının Mekanik Özellikleri. 4. Tarihi Eserlerin Güçlendirilmesi ve Geleceğe Güvenle Devredilmesi Sempozyumu, 27-29 Kasım, İstanbul, 185-193.

[17] Böke, H., Akkurt, S., İpekoğlu, B. 2004. Tarihi Yapılarda Kullanılan Horasan Harcl ve Sivalarinın Özellikleri, Yapı Dergisi, Cilt. 269, s.90-93.

[18] Değirmenci, N., Baradan, B. 2005. Chemical Resistance of Pozzolanic Plaster for Earthen Walls, Construction and Building Materials, Cilt. 19, s.536-542. DOI: 10.1016/j.conbuildmat.2004.12.00 2

[19] Nordmeyer, H., Taylor, P.R. 2007. Water Performance in Pozzolanic and Traditional Mortars. World of Coal Ash (WOCA), 7-10 May, Northern Kentucky, USA.

[20] Topçu, İ.B., Canbaz, M., Karanfil, H. 2005. Horasan Harç ve Betonunun Özellikleri. Yapı Mekaniği Semineri, 1 Temmuz, Eskişehir.

[21] Can, H., Ünay, A.İ. 2012. Tarihi Yapıların Deprem Davranışını Belirlemek için Sayısal Analiz Yöntemleri, Gazi Üniversitesi Mühendislik Mimarlı Fakültesi Dergisi, Cilt. 27, No. 1, s.211-217. 
[22] Drougkas, A. 2015. Derivation of the Properties of Masonry through Micro-modeling Techniques. Universitat Politecnica de Catalunya, PhD Thesis, 234 s, Barcelona.

[23] Page, A.W. 1978. Finite Element Model for Masonry, Journal of Structural Division, Cilt. 104, No. 8, s.1267-1285.

[24] Ghosh, A.K., Amde, A.M., Colville, J. 1994. Finite Element Modelling of Unreinforced Masonry. 10th International Brick/Block Masonry Conference, 5-7 July, Calgary, Canada, s.61-69.

[25] Şen, B. 2006. Modeling and Analysis of the Historical Masonry Structures. Boğaziçi University, Institute of Natural and Applied Science, M.Sc. Thesis, 85s, İstanbul.

[26] Lourenço, P.B. 1996. Computational Strategies for Masonry Structures. Delft University of Technology, PhD Dissertation, 220 s, Holland.

[27] Özen, G.Ö. 2006. Comparison of Elastic and Inelastic Behavior of Historic Masonry Structures at the Low Load Levels. METU, The Graduate School of Natural and Applied Sciences, Ms.C Thesis, 111s, Ankara.

[28] Oliver, J., Cervera, M., Oller, S., Lubliner, J. 1990. Isotropic Damage Models and Smeared Crack Analysis of Concrete, II International Conference on Computer Aided Analysis and Design of Concrete Structures, SCIC'90, 4-6 April, At Zell am See, Austria, s.945-958.

[29] LUSAS Finite Element System. FEA Ltd, Surrey, UK.

[30] Tezer, B.A. 2013. Damage Evaluation of Civil Engineering Structures under Extreme Loadings. İstanbul Technical University, Department of Civil Engineering, Structural
Engineering Programme, PhD. Thesis, 128s, İstanbul.

[31] Kachanov, L.M. 1958. On the Creep Fracture Time, Izv. Akad. Nauk USSR Otd. Tech., Cilt. 8, s.26-31.

[32] Capozucca, R. 2011. Experimental Analysis of Historic Masonry Walls Reinforced by CFRP under In-plane Cyclic Loading, Composite Structures, Cilt. 94, s.277-289. DOI: 10.1016/j.compstruct.2011.06.007

[33] Xu, C., Xiangli, C., Bin, L. 2012. Modeling of Influence of Heterogeneity on Mechanical Performance of Unreinforced Masonry Shear Walls, Construction and Building Materials, Cilt. 26, s.90-95.

DOI:10.1016/j.conbuildmat.2011.0 5.007

[34] Quinteros, R.D., Oller, S., Nallim, L.G. 2012. Nonlinear Homogenization Techniques to Solve Masonry Structures Problems, Composite Structures, Cilt. 94, s.724-730. DOI: 10.1016/j.compstruct.2011.09.006

[35] Köksal, H.O., Karakoç, C. 1999. An Isotropic Damage Model for Concrete, Materials and Structures/Matériaux et Constructions, Cilt. 32, s.611-617. DOI: $10.1007 / B F 02480497$

[36] Bazant, Z., Belytschko, T., Chang, T. 1984. Continuum Theory for Strain - Softening, Journal of Engineering Mechanics, Cilt. 110, No. 12, s.1666-1692. DOI: 10.1061/(ASCE)07339399(1984)110:12(1666)

[37] Cornelissen, H.A.W., Hordijk, D.A., Reinhardt, H.W. 1986. Experimental Determination of Crack Softening Characteristics of Normal Weight and Lightweight Concrete, HERON, Cilt. 31, No. 2, s.45-56.

[38] Lotfi, H.R., Shing, P.B. 1994. Interface Model Applied to Fracture of Masonry Structures, 
B. Doran ve S. Aktan / Hava Kireci Harcı Kullanılarak Üretilen Tarihi Yığma Duvarlarda Bünyesel Modelleme

Journal of Structural Engineering, Cilt. 120, No. 1, s.63-80. DOI: 10.1061/(ASCE)0733-9445(1994) 120:1(63)

[39] Lourenço, P.B., Rots, J. 1997. Multisurface Interface Model for Analysis of Masonry Structures, Journal of Engineering Mechanics, Cilt. 123, No. 7, s.660-668. DOI: 10.1061/(ASCE)0733-9399(1997) 123:7(660)

[40] Mehrabi, A.B., Shing, P.B. 1997. Finite Element Modeling of Masonry-Infilled RC Frames, Journal of Structural Engineering, Cilt. 123, No. 5, s.604-613. DOI: 10.1061/(ASCE)0733-9445(1997) 123:5(604)

[41] TS EN 772-1. 2012. Kâgir BirimlerDeney Yöntemleri-Bölüm 1: Basınç Dayanımının Tayini. Türk Standartları Enstitüsü, Ankara.

[42] TS EN 1015-11. 2000. Kagir Harcl Deney Metotları Bölüm 11: Sertleşmiş Harcın Basınç ve Eğilme Dayanımının Tayini. Türk Standartları Enstitüsü, Ankara.

[43] TS EN 13286-43. 2004. Bağlayıcısız ve hidrolik bağlayıcılı karışımlar Bölüm 43: Deney metodu - Hidrolik bağlayıcılı karışımların elâstiklik modülünün tayini, Türk Standartları Enstitüsü, Ankara.

[44] Autocad, AutoDesk Ltd, İsviçre.

[45] Aktan, S. 2016. Düzlem İçi Yükler Etkisindeki Yığma Duvarlarda Bünyesel Modelleme. Yıldız Teknik Üniversitesi, Fen Bilimleri Enstitüsü, Doktora Tezi, 169s, İstanbul. 